https://nv.nltu.edu.ua

https://doi.org/10.15421/40290610

Article received $10.06 .2019 \mathrm{p}$.

Article accepted 27.06.2019 p.

$@ \bowtie$ Correspondence author удк 712.4-025(477.62)

М. Ю. Осіпов, Ю. А. Величко, С. А. Масловата, В. Л. Кульбіцький

Уманський національний університет садівництва, м. Умань, Україна

\title{
ПРОЕКТ РЕКОНСТРУКЦІЇ ШАХТАРСЬКОГО БУЛЬВАРУ В МІСТІ ВУГЛЕДАР ДОНЕЦЬКОЇ ОБЛАСТІ
}

\begin{abstract}
Проаналізовано сучасний стан озеленення території Шахтарського бульвару в місті Вугледар Донецької області. Ландшафтний аналіз території об'єкта показав, що Шахтарський бульвар, розташований у центрі міста Вугледар Донецької області, має регулярний стиль планування. Встановлено, що в балансі території бульвару споруди займають 1,3 \%, дорожньостежкова мережа - 27,8 \%, деревно-кущові насадження - тільки 5 \%, квітники - 1,5\%, деградовані газони та пусті ділянки $64,4 \%$, що не відповідає нормативам озеленення, прийнятим в Україні. Окрім цього, відсутні водні облаштування; недостатньо таких елементів благоустрою, як: лави, ліхтарі та урни; відсутній тротуар вздовж південної сторони бульвару. Проведено інвентаризацію деревних і чагарникових порід. Складено інвентаризаційну таблицю зелених насаджень, на основі якої зроблено висновки та внесено пропозиції щодо реконструкції та відновлення зелених насаджень та благоустрою території. Реконструкція озеленення території Шахтарського бульвару полягатиме у створенні нових декоративних насаджень. Для озеленення території підібрано асортимент рослин згідно з грунтово-кліматичними умовами району. Планування території здійснено за допомогою застосування різних типів і форм рослинних насаджень: алей, груп, солітерів, газонів, живоплотів та бордюрів, квітковим оформленням ділянки та вертикального озеленення. Проектними пропозиціями передбачено висадження 438 саджанців дерев, 4512 кущів, 24 ліани, 758 саджанців троянд і 746 однорічників, цибулинних квітів і трав'яних багаторічників.
\end{abstract}

Ключові слова: реконструкція; озеленення міст; благоустрій; бульвар; ситуаційний план; генеральний план; ландшафтне проектування.

Вступ. Благоустрій та озеленення населених місць має велике значення в житті людини, значно впливає на навколишнє середовище. Загалом у світі докладають значних зусиль із озеленення та благоустрою міського середовища, створюють умови для населення, які забезпечують високий та комфортний рівень життя. В Україні також спостерігають тенденцію до підвищення містобудівельної ролі зелених насаджень, усвідомлюють їх естетичне, екологічне та рекреаційне значення в озелененні міста, створенні його зовнішнього вигляду (Kucheriavii, 2005; Krizhanovskaia, 2005; Rubtcov, 1977).

Незамінною є містобудівельна, рекреаційна та декоративна роль зелених насаджень. Бульвари, алеї, сквери, сади і парки не тільки прикрашають місто, надають йому особливого колориту, підкреслюючи красу архітектурних споруд, приховуючи недоліки будівництва, але і є місцем для рекреації жителів (Barabanova, 2010; Bogovaia, 1990). Всесвітня організація охорони здоров'я рекомендує мати в містах не менше $50 \mathrm{~m}^{2}$ зелених насаджень на одного мешканця, аналогічний норматив прийнято і в Україні. На жаль, ця норма озеленення $є$ недосяжною у багатьох містах, зокрема і в м. Вугледар.

Мета дослідження - розроблення проектних пропозицій з реконструкції та формування зелених насаджень шахтарського бульвару в м. Вугледар Донецької обл.

Об'єкт дослідження - сучасний стан декоративних насаджень та реконструкція території шахтарського бульвару в м. Вугледар Донецької обл.

Методи дослідження - біоекологічні, лісівничі, топографічні, методи ландшафтної графіки.

Результати дослідження. Шахтарський бульвар, який було збудовано у 1985 р., розташований у центрі м. Вугледар, має прямокутну форму, протяжністю зі сходу на захід 320 м, шириною 80 м та займає площу 2,6 га.

Останню реконструкцію бульвару проводили у 2007 р., під час якої замінили покриття доріжок, встановили дитячий майданчик та нові малі архітектурні форми: лави та урни. Відкрили пам'ятник загиблим шахтарям та встановили три пам'ятні плити на честь загиблих

Інформація про авторів:

Осіпов Михайло Юрійович, канд. с.-г. наук, доцент, кафедра садово-паркового господарства. Email: m3dsad@gmail.com; https://orcid.org/0000-0001-7004-1164

Величко Юлія Анатоліївна, канд. с.-г. наук, доцент, кафедра садово-паркового господарства. Email: julyavel4ko@ukr.net; https://orcid.org/0000-0002-7793-1124

Масловата Світлана Андріївна, канд. с.-г. наук, викладач, кафедра лісового господарства. Email: svetlana_maslovataya@meta.ua; https://orcid.org/0000-0002-5725-0604

Кульбіцький Володимир Леонідович, канд. с.-г. наук, викладач, кафедра лісового господарства. Email: kulbitsky@i.ua; https://orcid.org/0000-0003-4435-2115

Цитування за ДСтУ: Осіпов М. Ю., Величко Ю. А., Масловата С. А., Кульбіцький В. Л. Проект реконструкції Шахтарського бульвару в місті Вугледар Донецької області. Науковий вісник НлтУ України. 2019, т. 29, № 6. С. 49-53.

Citation APA: Osipov, M. Yu., Velicho, Yu. A., Maslovata, S. A., \& Kulbitskyi, V. L. (2019). Development project of Shakhtarskyi boulevard in Vugledar city of Donetsk region. Scientific Bulletin of UNFU, 29(6), 49-53. https://doi.org/10.15421/40290610 
у Великій Вітчизняній війні, учасників ліквідації аварії на Чорнобильській AEC та воїнів-афганців. У 2009 р. встановили два дитячі майданчики, оновили лави та урни. У 2017 р. за рішенням суду провели демонтаж кафе, який було збудовано без необхідного дозволу в центрі бульвару напроти сцени.

Шахтарський бульвар має передусім регулярний стиль планування, головну вісь, відносно якої симетрично розташовані інші ландшафтні елементи. Зі східної сторони бульвару розташований Вугледарський міський культурно-дозвіллєвий центр із концертною залою на 350 місць та кафе "Театральне" разом 3 прилеглим сквером; $з$ північної сторони - житлові дев'ятиповерхові будинки та відділення банку; 3 південної - міський ринок, торгові кіоски та житлові п'ятиповерхові будинки. Зі західної сторони є дорога та житловий масив 3 десятиповерхових будинків.

3 ландшафтного аналізу території видно, що в балансі території бульвару Шахтарський споруди займають 1,3\%, дорожньо-стежкова мережа - 27,8 \%, деревно-кущові насадження - тільки $5 \%$, квітники - 1,5\%, деградовані газони та пусті ділянки - 64,4 \%, що не відповідає нормативам озеленення, прийнятим в Україні. Окрім цього, відсутні водні облаштування; недостатньо таких елементів благоустрою, як лави, ліхтарі та урни; відсутній тротуар вздовж південної сторони бульвару. Загалом територія бульвару потребує реконструкції.

За інформацією, яку надав виконавчий комітет Вугледарської міської ради, показники стану зелених насаджень міста становлять: загальна площа насаджень 32,23 га; площа зелених насаджень загального користування - 29,73 га із загальною кількістю висаджених зелених насаджень 20 тис. одиниць. Асортимент рослин Шахтарського бульвару навели в таблиці.

Таблиця. Асортимент рослин Шахтарського бульвару

\begin{tabular}{|c|c|c|c|}
\hline \multirow{2}{*}{$\begin{array}{l}\text { № } \\
3 / \text { П }\end{array}$} & \multicolumn{2}{|c|}{ Назва рослин } & \multirow{2}{*}{$\begin{array}{c}\text { Кіль- } \\
\text { кість, } \\
\text { шт. }\end{array}$} \\
\hline & українська назва & латинська назва & \\
\hline \multicolumn{4}{|c|}{ Хвойні дерева } \\
\hline 1 & Сосна звичайна & Pinus sylvestris L. & 3 \\
\hline 2 & Туя західна & Thuja occidentalis L. & 41 \\
\hline 3 & Ялина колюча & Picea pungens Engelm. & 41 \\
\hline \multicolumn{4}{|c|}{ Листяні дерева } \\
\hline 4 & Абрикос звичайний & Armeniaca vulgaris Lam. & 6 \\
\hline 5 & Береза повисла & Betula pendula L. & 29 \\
\hline 6 & Верба матсудана & Salix matsudana Koidz. & 1 \\
\hline 7 & $\begin{array}{l}\text { Гіркокаштан зви- } \\
\text { чайний }\end{array}$ & Aesculus hippoce & 48 \\
\hline 8 & Горіх волоський & Juglans regia $\mathrm{L}$. & 11 \\
\hline 9 & Горобина середня & $\begin{array}{l}\text { Sorbus intermedia (Ehrh.) } \\
\text { Pers }\end{array}$ & 48 \\
\hline 10 & Груша звичайна & Pyrus communis L. & 1 \\
\hline 11 & Клен гостролистий & Acer platanoides L. & 31 \\
\hline 12 & Клен - явір & Acer pseudoplatanus L. & 5 \\
\hline 13 & Липа серцелиста & Tilia cordata Mill. & 9 \\
\hline 14 & Тополя біла & Populus alba L. & 11 \\
\hline 15 & Тополя бальзамічна & $\begin{array}{l}\text { Populus trichocarpa Torr. \& } \\
\text { A. Gray }\end{array}$ & 61 \\
\hline 16 & Черемха звичайна & Prunus padus L. & 9 \\
\hline 17 & Яблуня домашня & $\begin{array}{l}\text { Malus domestica (Borkh.) } \\
\text { Borkh. }\end{array}$ & 3 \\
\hline 18 & Ясен звичайний & Fraxinus excelsior L. & 3 \\
\hline \multicolumn{4}{|c|}{ Кущі } \\
\hline 19 & Бирючина звичайна & Ligustrum vulgare L. & \\
\hline 20 & Бузок звичайний & Syringa vulgare L. & 8 \\
\hline 21 & Калина звичайна & Viburnum opulus L. & 40 \\
\hline 22 & Шипшина собача & Rosa canina L. & 6 \\
\hline \multicolumn{4}{|c|}{ Ліани } \\
\hline 23 & Kaмncic & Campsis radicans & 5 \\
\hline
\end{tabular}

50 Науковий вісник НЛтУ України, 2019, т. 29, № 6
На території є невелика кількість дерев у пригніченому стані внаслідок багаторічного недбалого ставлення до зелених насаджень. Існуючі клумби мають малий асортимент рослин, тому їх загальний стан потребує реконструкції і розширення.

Пропонуємо деякі композиції виконати в пейзажному стилі без принципових суперечностей стилів. Адже, як вважає А. Регель, регулярність і абсолютна геометричність - це різні поняття і в регулярному плануванні допускається застосування об'єктів однакового оптичного значення замість об'єктів однакової форми і міри (Regel, 1896).

На території пропонуємо зберегти насадження всіх дерев, які перебувають у задовільному стані. Вирубці підлягають дерева Sorbus intermedia (Ehrh.) Pers, оскільки вони перебувають у незадовільному стані. Також пропонуємо поступово замінити рядове насадження Роpulus trichocarpa Torr. \& A. Gray уздовж північної сторони бульвару на Populus nigra L., оскільки 30-річні існуючі насадження мають низьку декоративну якість, багато суховерхівкових та хворих дерев. Після інвентаризації видно, що 60-річні дерева Populus alba L., що ростуть у східній частині бульвару, перебувають у кращому стані, ніж 30-річні дерева Populus trichocarpa.

Враховуючи інтереси населення усіх вікових категорій, пропонуємо виділити на території бульвару кілька функціональних зон: вхідна, меморіальна, зона для тихого відпочинку, дитячий майданчик, зона відпочинку для спілкування молоді, пішохідний фонтан, головна та другорядні алеї бульвару (рис. 1).

Облаштовуючи вхідну зону у центрі короткої сторони в західній частині бульвару, доцільно висадити паркову групу рослин, що складається з трьох частин, загальною шириною 10 м. У центрі алеї встановити малу архітектурну форму (МАФ) у вигляді скульптури кованої пальми, а за нею, уздовж головної осі бульвару, вісім бетонних ваз з однорічними квітами Petunia hybri$d a$ Vilm. (рис. 2, 3). По обидві сторони центральної алеї пропонуємо влаштувати місця для відпочинку - вісім лав $з$ трельяжами, обсадженими Parthenocissus quinquefolia (L.) Planch. для створення затінку. Біля вхідної зони - два Acer platanoides 'Globosum' на штамбі та два кущі Deutzia scabra Thunb.

У західній частина бульвару переважають відкриті простори, тому існуючі насадження доцільно доповнити двома змішаними деревно-кущовими групами 3 декоративно-квітучих видів кущів та дерев (Pinus sylvestris L., Betula pendula Roth, Fraxinus excelsior L., Corylus avellana 'Atropurpurea', Acer platanoides L., A. campestre L., A. tataricum L., Sorbus aucuparia L., Padus avium Mill., Aronia melanocarpa (Michx.) Elliott, Philadelphus coronarius L., Ph. lewisii Pursh, Sambucus nigra L. та Viburnum opulus L.). Центральну частину пропонуємо зробити у вигляді партеру зі симетрично розташованих дванадцяти клумб чайно-гібридних троянд 'Gloria Dei', розташованих усередині бордюру квадратної форми з Buxus sempervirens L. Така форма підкреслить регулярність, у середині якої на передньому плані зростатимуть жовто-рожеві троянди, а на задньомуMiscanthus sinensis Andersson 3 рожевим забарвленням суцвіть, який квітне зі серпня по жовтень. 


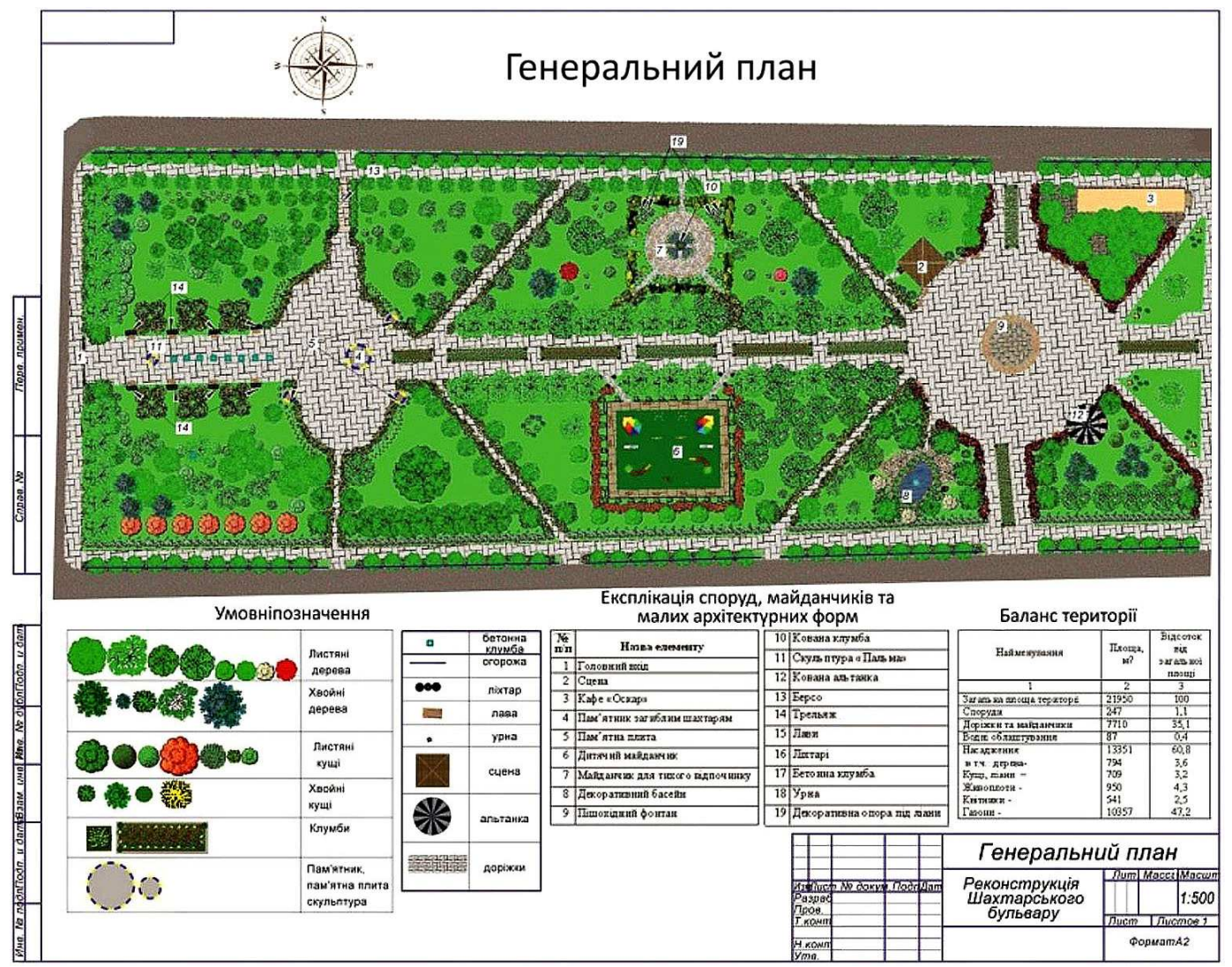

Pис. 1. Генеральний план Шахтарського бульвару в м. Вугледар Донецької обл.

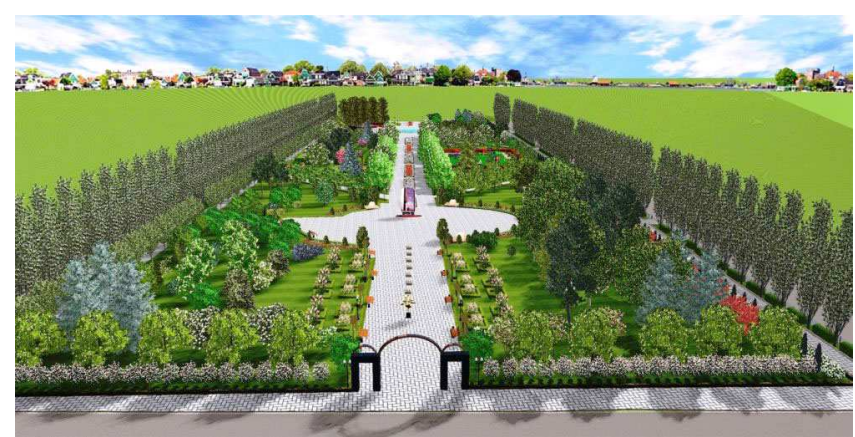

Рис. 2. Вхідна зона

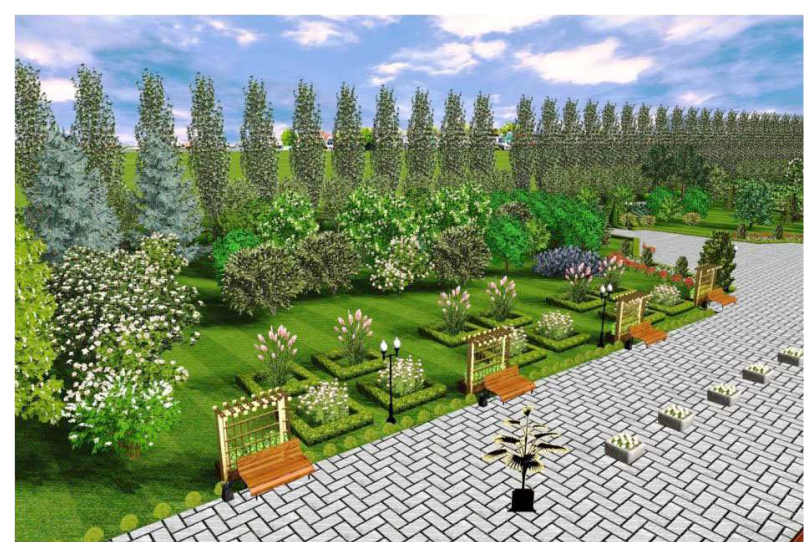

Рис. 3. Центральна алея біля вхідної зони

Периметром західної частини бульвару заплановано висадити рядові насадження Juniperus sabina Monna 'Calgary Carpet' - 66 шт., Lonicera tatarica L. - 36 шт. та Gleditsia triacanthos L. - 10 шт. Ці рослини є невибагливими і добре зростають в умовах міста.

Меморіальну частину, де встановлений пам'ятник загиблим шахтарям, пропонуємо обрамити бордюром із вічнозеленого B. sempervirens, розбити клумби з грунто- покривних троянд білого 'Snow Dance' (60 шт.) та яскраво-червоного кольору 'Red Mikado' (80 шт.), між якими буде чергуватися Th. occidentalis 'Golden Globe' (30 шт.). Біля трьох монументів заплановано висадити Morus alba 'Pendula'. Вхід на площу акцентуємо Th. occidentalis 'Brabantта' та складними стриженими формами з $B$. sempervirens.

На ділянках з обох сторін центрального пам'ятника доречно висадити Magnolia $\times$ soulangeana Soul.-Bod. на фоні ряду Platycladus orientalis (L.) Franco - як солітер, та Platanus acerifolia (Aiton) Willd. на фоні Carpinus betulus L.

Територію тихого відпочинку (рис. 4), розміром $22 \times 20$ м, пропонуємо влаштувати на пустинній ділянці бульвару. По периметру майданчика заплановано висадити формований живопліт - боскет з Carpinus betulus 2 м заввишки. Заспокійливий ефект мають рослини холодних тонів, а також квіти білих, синіх та фіолетових кольорів. Так, на території запроектовано висадити: білі троянди двох сортів 'Claire Austin' (4 шт.) та 'Aspirin Rose' (18 шт.), Clematis 'Piilu', $C$. 'The President', $C$. 'Mrs N Thompson', C. 'Multi Blue', білі та фіолетові Petunia hybrida, дві білі Hydrangea arborescens L., Narcissus tazetta L., чотири біло-рожеві кущі Syringa vulgaris L., Cotoneaster dammeri C. K. Schneid. (64 шт.), Juniperus horizontalis 'Blue Chip' з голубою хвоєю (64 шт.). Регулярність та контраст підкреслять конусоподібні форми Platycladus orientalis 'Aurea Nana' (14 шт.). У центрі пропонуємо влаштувати клумбу з однорічниками Petunia grandiflora 'Tango Blue Star' (32 шт.), навколо якої є квітник, який складається 3 чотирьох однакових сегментів круга, з Juniperus horizontalis 'Blue Chip', Narcissus 'Ice Follies' (100 шт.) та Petunia milliflora 'Picobella' F1 (52 шт.). 


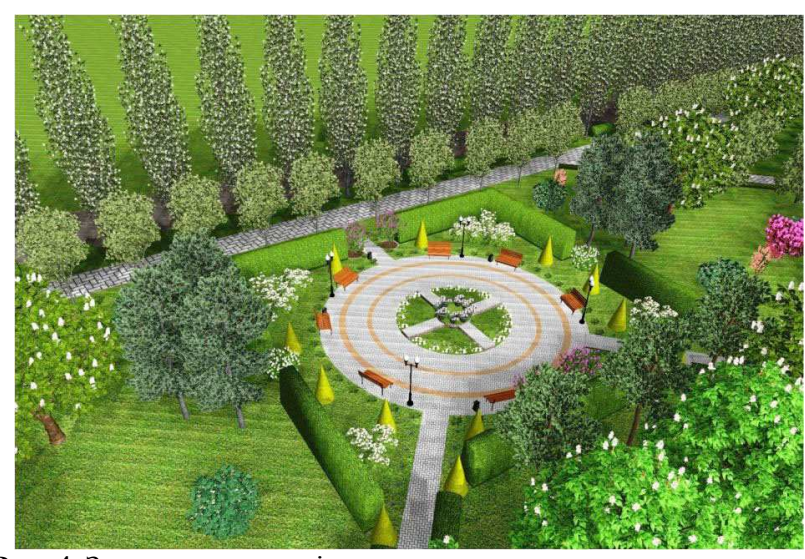

Рис. 4. Зона для тихого відпочинку, вигляд зверху

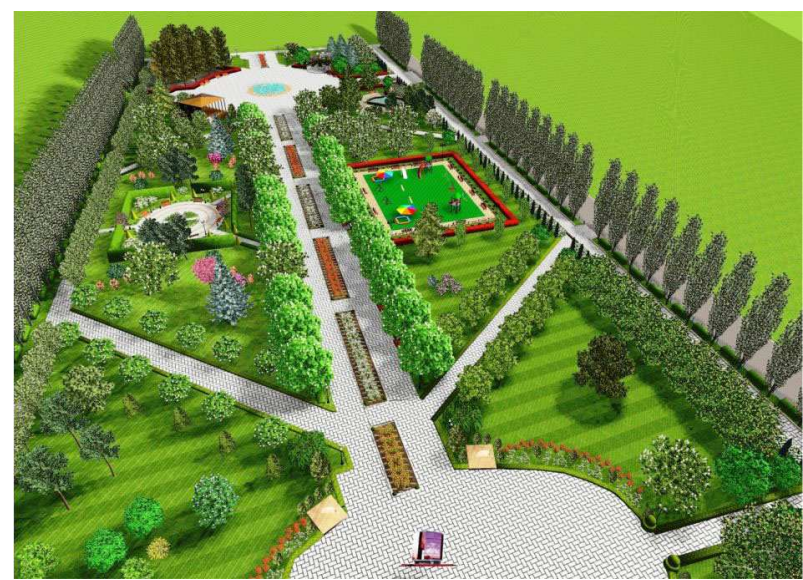

Рис. 5. Центральна частина бульвару

Навпроти зазначеного вище майданчика для спокійного відпочинку, через головну алею розташований дитячий ігровий майданчик (рис. 5). Пропонуємо зробити до нього два входи з боку головної алеї, навколо висадивши Juniperus communis 'Repanda' (58 шт.) та $Q u$ ercus robur 'Fastigiata Koster' пірамідальної форми (8 шт.). Фітонциди $Q$. robur та $J$. communis мають велику бактерицидність, пригнічуючи зростання багатьох патогенних для людини мікроорганізмів. Тому саме ці рослини варто посадити навколо дитячого майданчика. Функцію живоплоту та яскравого акценту виконає Physocarpus opulifolius (L.) Maxim. 'Diabolo' (113 шт.), який пропонуємо висадити з трьох сторін майданчика.

Зону відпочинку для спілкування молоді (для проведення майстер-класів, літературних вечорів, конкурсів) пропонуємо створити на території біля центральної площі, де раніше знаходилось кафе, напроти сцени. Для цього необхідно встановити велику ковану альтанку, в середині якої обладнати зону відпочинку, по периметру якої, для створення необхідної тіні й затишку, варто висадити ліани - Parthenocissus quinquefolia (10 шт.), з боку спроектувати красиво-квітучі кущі: Syringa vulgaris 'Mme Lemoine' (2 шт.), S. vulgaris 'Pamyat o Vavilove' (2 шт.), S. vulgaris 'Taras Bulba' (2 шт.) та три екземпляри Deutzia scabra, що, чергуючись, квітуватимуть 3 травня по липень.

У центрі площі, діаметром 45 м, спроектовано оздобити "сухий" або пішохідний фонтан. Він підвищить вологість, знизить температуру повітря, тобто буде кондиціонером у спекотну пору року. У конструкції пропонуємо використати підсвічування, завдяки чому споруда перетвориться на динамічний об'єкт, збагатить та урізноманітнить існуючий звичайний міський ландшафт.
Головна та другорядні алеї бульвару. Уздовж головної алеї розташовані сім прямокутних зелених клумб острівців, які пропонуємо оформити багаторічниками Aster novi-belgii 'Royal Ruby' (416 шт.), висотою 3050 см блакитного кольору. У центральній частині Rosa floribunda 'Leonardo da Vinci' червоного (256 шт.) та рожевого (272 шт.) кольорів. У кутах кожної клумби висадити карликову Thuja occidentalis 'Tiny Tim' (по 4 шт., загалом - 36 шт.). У центральній частині бульвару пропонуємо висадити бордюр із Mahonia aquifolium (Pursh) Nutt., а до алеї з існуючими деревами Aesculus hippocastanum L. додати Catalpa speciosa (20 шт.), декоративну своїм великим листям і квітками.

Навколо центральної площі проектом передбачено зробити живопліт з Berberis ottawensis 'Superba' висотою 0,8 м. Для вертикального озеленення напіввідкритої сцени пропонуємо висадити два кущі Parthenocissus quinquefolia. Вздовж центральної алеї влаштувати зручні паркові лави - 27 шт., урни - 27 шт., ліхтарі - 21 шт. На другорядних алеях, що примикають до головної, спроектовано створити бордюр із Buxus sempervirens, висадити рядові насадження на одній алеї Crataegus oxyacantha 'Paul's Scarlet' (12 шт.), на другій - Robinia pseudoacacia 'Umbraculifera' (10 шт.) на штамбі.

Між проїжджою частиною і тротуаром вздовж бульвару пропонуємо зробити алейні насадження Populus nigra var. pyramidalis Spach (чоловічі екземпляри, які не утворюють пуху) або Populus alba 3 відстанню між деревами 4 м. Між ними - формований живопліт $3 \mathrm{Li}$ gustrum vulgare висотою до 1 м. Ці рослини добре витримують міські умови та загазованість повітря, тому будуть надійною "ширмою" від пилу та шуму. 3 південної сторони бульвару по іншу сторону тротуару - живопліт 3 Spiraea $\times$ vanhouttei (Briot) Zabel (140 шт.) та рядове насадження Juniperus scopulorum 'Blue Arrow' (87 шт.). 3 протилежної сторони бульвару - рядове насадження Tilia tomentosa Mill. (41 шт.), яка створить затишок і матиме гарний декоративний вигляд, особливо під час цвітіння (червень-липень). Цей вид липи вирізняється посухостійкістю, що є доречним для посушливого Донбасу.

Ялини та багаторядні насадження рослин будуть виконувати захисну функцію території бульвару від шуму та пилу зі сторони проїжджої частини, створять затишок та комфортні умови для відпочинку. Важливою характеристикою рослин, що пропонуємо висадити по периметру бульвару, є їхні швидкі темпи росту.

На двох клумбах трикутної форми доцільно замінити старі дерева Malus domestica, які вже втратили свою декоративність, створивши кругову композицію 3 вічнозеленої Yucca filamentosa L. (24 шт.), в центрі якої Rhus hirta (L.) Sudw. (2 шт.). По периметру клумб варто висадити бордюр 3 Thuja occidentalis 'Golden Globe' (170 шт.). У двох кутах кожної клумби пропонуємо невеликі композиції 3 низьких ялівців контрастного кольору: по три рослини Juniperus horizontalis 'Golden Carpet' та один Juniperus 'Depressa Aurea'.

На території, вільній від майданчиків та алейних насадження рослин, пропонуємо висадити: поодинокі дерева (Larix decidua Mill., Malus niedzwetzkyana Dieck ex Koehne), групи 3 хвойних порід (Pinus sylvestris L., Pinus nigra) та невеликі змішані декоративні деревно-кущові групи рослин: 
- Abies concolor 'Violacea', Prunus cerasifera 'Nigra', Cotinus coggygria Scop., Tamarix gracilis Willd.;

- Crataegus monogyna Jacq., Tamarix gracilis;

- Abies concolor 'Compacta', Prunus triloba Lindl., Juniperus horizontalis 'Golden Carpet';

- Acer pseudoplatanus L., Acer platanoides L., Forsuthia suspensa, Crataegus monogyna.

\section{Висновки:}

1. Реконструкція озеленення території Шахтарського бульвару полягатиме у створенні нових декоративних насаджень 3 підібраного асортименту рослин згідно 3 грунтово-кліматичними умовами району. Планування озеленення здійснили за допомогою застосування різних типів і форм рослинних насаджень: алей, груп, солітерів, газонів, живоплотів та бордюрів, влаштування клумб та вертикального озеленення.

2. Проектними пропозиціями передбачено висадження 438 саджанців дерев, 4512 кущів, 24 ліани, 758 саджанців троянд і 746 однорічників, цибулинних квітів i трав'яних багаторічників.

3. Важливим напрямом 3 вдосконалення цього об'єкта $\epsilon$ також благоустрій території, що передбачає створення двох нових зон для тихого відпочинку, облаштування дитячого ігрового майданчика гумовим покриттям, pe- конструкцію тротуарів уздовж бульвару, заміну огородження території, встановлення малих архітектурних форм, виконаних в єдиному стилі (паркової вхідної групи, кованої альтанки, кованої клумби, скульптури "Пальма"), освітлення території бульвару, влаштування пішохідного фонтану, реконструкцію декоративного басейну.

\section{Перелік використаних джерел}

Barabanova, A. V. (2010). Ozelenenie prishkolnogo uchastka: rekomendatcii, planirovanie raboty, spravochnye materialy. Volgograd: Uchitel, 131 p. [In Russian].

Bogovaia, I. O. (1990). Ozelenenie naselennykh mest. Moscow: Agropromizdat, 237 p. [In Russian].

Krizhanovskaia, N. Ia. (2005). Osnovy landshaftnogo dizaina. Moscow: Feniks, 204 p. [In Russian].

Kucheriavii, V. P. (2005). Ozelenennia naselenikh mistc. Lviv: Svit, 456 p. [In Ukrainian].

Regel, A. (1896). Iziashchnoe sadovodstvo i khudozhestvennye sady. Istoriko-didakticheskii ocherk. St. Petersburg: Publishing House G. B. Vinkler, 448 p. [In Russian].

Rubtcov, L. I. (1977). Derevia i kustarniki v landshaftnoi arkhitekture. Kiev: Science, 375 p. [In Russian].

M. Yu. Osipov, Yu. A. Velichko, S. A. Maslovata, V. L. Kulbitskyi Uman National University of Horticulture, Uman, Ukraine

\section{DEVELOPMENT PROJECT OF SHAKHTARSKYI BOULEVARD} IN VUGLEDAR CITY OF DONETSK REGION

The current state of Shakhtarskyi Boulevard landscaping in Vugledar city in Donetsk Region is analyzed. Landscape analysis of the site showed that Shakhtarskyi Boulevard, located in the city center of Vugledar, Donetsk Region, has a regular planning style. It is established that in the balance of the boulevard territory the buildings occupy $1.3 \%$, the road and path network $-27.8 \%$, the tree and shrubbery plantings - only $5 \%$, flower beds $-1.5 \%$, degraded lawns and non-producing sections $-64.4 \%$, which does not meet the planting standards adopted in Ukraine. Moreover, there are no water facilities; such elements of accomplishment as benches, lanterns and urns are not enough; there is no sidewalk along the southern side of the boulevard. The inventory of the tree and shrubbery plantings has been carried out. An inventory table of green plantations has been drawn up, on its basis the conclusions and suggestions regarding the reconstruction and restoration of green plantations and landscaping of the territory are made. Reconstruction of planting of the Shakhtarskyi Boulevard territory consists in the creation of new decorative plantations. The assortment of plants for the territory landscaping has been selected according to the soil and climatic conditions of the district. The territory planning was carried out by applying different types and forms of planting: alleys, groups, single plantings, lawns, hedges and borders, floral design of the site and vertical landscaping. Taking into account the interests of the population of all age categories, we propose to allocate several functional zones on the territory of the boulevard: an entrance zone, a memorial zone, a zone for quiet rest, a children's playground, a recreation area for young people, a pedestrian fountain, main and secondary alleys of the boulevard. Project proposals include the planting of 438 tree seedlings, 4512 shrubs, 24 lianas, 758 rose plants and 746 annuals, bulb flowers, and herbaceous perennials. An important area for improvement of this object is also the site improvement, which involves the creation of two new zones for quiet rest, the arrangement of a children's playground with a rubber coating, the reconstruction of pavements along the boulevard, the perimeter fence replacement, the installation of small architectural forms, executed in a single style (park entrance group, wrought iron pergola, wrought iron flowerbed, a "Palm" sculpture), the illumination of the boulevard territory, the arrangement of a pedestrian fountain, the decorative pool reconstruction.

Keywords: reconstruction; city landscaping; improvement; boulevard; site plan; landscape design. 